\title{
Herpetological Journal \\ https://doi.org/10.33256/hj29.4.274281 \\ Spatial patterns of snake diversity in an urban area of north-east Brazil
}

\author{
Rafaela C. França ${ }^{1,2}$ \& Frederico G. R. França ${ }^{3}$ \\ ${ }^{1}$ Programa de Pós-graduação em Ecologia e Conservação da Biodiversidade, Universidade Estadual de Santa Cruz - UESC, Rodovia Jorge Amado, Km 16, CEP 45662-900 - Salobrinho, BA, Brazil \\ ${ }^{2}$ Herpetology Section, Zoologisches Forschungsmuseum Alexander Koenig, Adenauerallee 160, 53113 Bonn, Germany \\ ${ }^{3}$ Departamento de Engenharia e Meio Ambiente, Centro de Ciências Aplicadas e Educação, Universidade Federal da Paraíba - UFPB, CEP 58297-000, Rio Tinto, PB, Brazil
}

\begin{abstract}
The distribution of animal populations within an assemblage includes a wide variety of patterns, which are fundamental to understanding population dynamics and aid in conservation actions. We examined a snake assemblage in an urban area to describe species distribution patterns and to identify which places are more likely to contain snakes, both venomous and non-venomous. The study was conducted in the urban area of the municipality of Rio Tinto in north-east Brazil. We used a geostatistical modelling technique called ordinary kriging to identify which places were more likely to contain snakes, and a statistical spatial method (average nearest neighbour distance) to detect distribution patterns of snake species within the study area. A total of 291 individuals distributed among 28 species were recorded. The snakes were found in streets, homes, churches, university campus, streams, and even in local supermarkets. Ordinary kriging showed that the area of distribution of individuals was concentrated at three distinct points located in the centre of the urban area. The significant results of the average nearest neighbour distance analysis showed a clustered distribution for two species and dispersed distributions for eight species. Information on urban sites where snakes are more likely to be found is important not only for conservation, but also to help local citizens better understand and live amongst snakes.
\end{abstract}

Keywords: geostatistical, kriging, urban herpetology, interpolation, urbanisation

\section{INTRODUCTION}

$\mathrm{T}^{\mathrm{T}}$ he anthropogenic transformation of natural ecosystems is a serious threat to worldwide biological diversity (Hamer \& Mcdonnell, 2010), as it is a major cause of species extinction (McKinney, 2006). As the human population grows and urban areas expand, original habitats are lost, fragmented, or modified, reducing local biodiversity. However, few studies have been conducted on wildlife in urban environments, especially snakes (Mitchell et al., 2008). Furthermore, even when conducted in urban areas, most studies focus on protected areas instead of the surrounding urban matrix. Indeed, very few studies have been conducted in areas with intense anthropogenic influence, particularly in South and Central America (Mitchell \& Jung Brown, 2008; Rojas-Morales, 2012).

Studies on snake distribution patterns in urban areas can help both snakes and people. This knowledge is essential to assist the local population, since the places where venomous species are found will be known; also, it is possible to prevent and support local medical staff in cases of snakebite accidents (Brites \& Bauab, 1988). Additionally, these studies allow us to evaluate the degree of plasticity of species, pointing out which species are restricted to preserved areas and which can deal with the alteration of the natural environment (Barbo, 2008). In Brazil, some studies have addressed the ecology of snakes inhabiting urban areas (e.g. Silva \& Ferreira, 1988; Brites \& Bauab, 1988; Marques et al., 2009; Barbo et al., 2011; França et al., 2012), while others only mentioned species found in these anthropic environments (e.g. São Pedro \& Pires, 2009; Bernarde \& Machado, 2002; Santos et al., 2005; Costa et al., 2010). Furthermore, most studies were restricted to south and south-east Brazil, and almost none were conducted in north-east Brazil (but see Sales et al., 2009; França et al., 2012).

The distribution of animal populations includes a wide variety of patterns, and although they are key to understanding a population's ecology, they are extremely difficult to describe precisely (Clark \& Evans, 1954). Once distribution patterns are found and described, it is also important to discover which factors are responsible for each pattern and what mechanisms produce and maintain them (Levin, 1992).

Methods using modelling have become important tools to understand the spatial distribution of species (Jenkins et al., 2009). Several approaches to modelling have been used to determine variations in the spatial distribution of snakes, such as logical approaches (rule- 

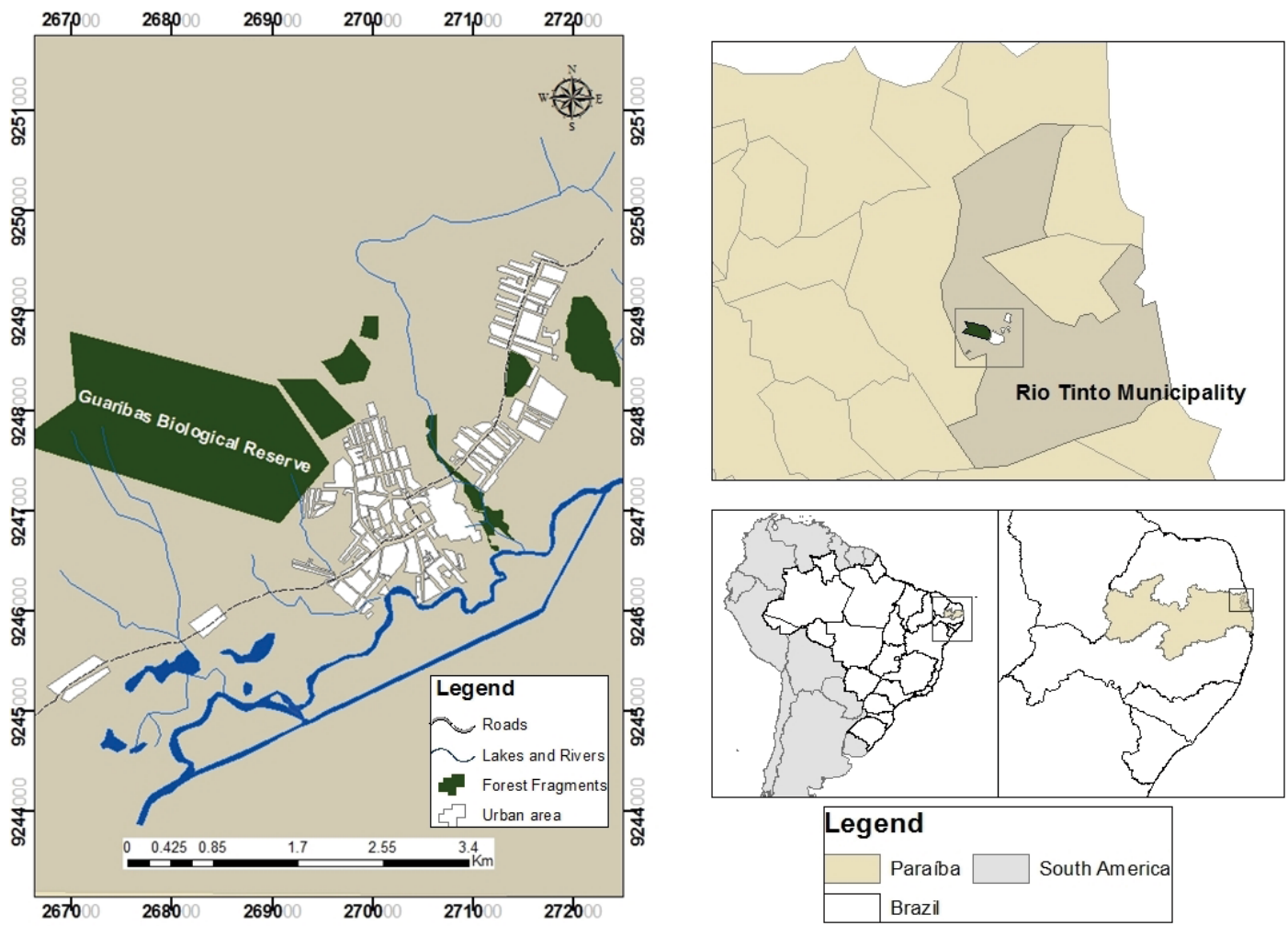

Figure 1. Study area showing the northern coast of Paraíba State, underscoring the urban area of Rio Tinto municipality and the Guaribas Biological Reserve.

based; e.g. Scott et al., 2002); statistical approaches (trapping/observation probability; e.g. Peterson et al., 2002), Mahalanobis distances (e.g. Browning et al., 2005), logistic regression (e.g. Cooper-Doering, 2005), Euclidean distance analysis (e.g. Bieser, 2008; Degregorio, 2008), and geostatistical approaches (kriging; e.g. Lee \& Peterson, 2003). Among these, the geostatistical approach is different from the others because it does not require habitat information to determine the potential distribution of species (Jenkins et al., 2009). Furthermore, while most traditional statistical techniques assume data independence, the geostatistical approach is based on the principle that the difference in the values of a given variable at two points depends on the distance between them (Dal Prá et al., 2011). Although Lee \& Peterson (2003) showed that geostatistical models are more suitable for determining the potential distribution of some snake species than models that use information on habitats, few studies have used this analysis for snakes (e.g. Brito et al., 2008; Martínez-Freiría et al., 2009; Lee \& Peterson, 2003), and none of these were conducted with Brazilian snake populations.

The aim of this study was to examine the spatial distribution of the snake assemblage in the urban area of the municipality of Rio Tinto, north-east Brazil, using a geostatistical modelling technique and statistical spatial method to describe the distribution pattern of the species in the area. We tested the hypothesis that snakes should present a clustered distribution because they use only suitable spots in the urban matrix. Finally, we identified which places are more likely to contain snakes, both venomous and harmless to humans.

\section{METHODS}

\section{Study area}

The spatial distribution of snakes in the assemblage was studied between August 2009 and September 2012 in the urban area of the Rio Tinto municipality $\left(06^{\circ} 48^{\prime} 10^{\prime \prime} \mathrm{S}\right.$ and $35^{\circ} 04^{\prime} 51^{\prime \prime}$ W), north-east Brazil (Fig. 1). The Rio Tinto municipality covers approximately $466 \mathrm{~km}^{2}$ and has a humid tropical or non-arid climate ( $A w$ in the Koppen classification), with a rainy season between February and October and average annual precipitation of $1.634 \mathrm{~mm}$ (Beltrão et al., 2005). The urban area of Rio Tinto is located in the centre of the municipality. At the north-west of the urban area, there is a 327.0 ha patch of protected area (Guaribas Biological Reserve) (Fig. 1) with two different types of forest formations: a forested habitat (Floresta Estacional semidecidual) and an arboreous open savanna (Tabuleiro) (Oliveira-Filho \& Carvalho, 1993; Mesquita et al., 2018). It is considered a refuge for local biodiversity.

The Rio Tinto municipality is located in the Brazilian Atlantic Forest. It has approximately 24,000 human inhabitants and has suffered from increasing urbanisation since 1920s, when a Swedish family (Lundgren family) decided to install a textile factory in the city (the Companhia de Tecidos Rio Tinto) (Rosa, 2010). There are 28 species of snakes known for Rio Tinto, which also has the second highest rate of accidents caused by the genus Bothrops in the state of Paraiba (Albuquerque et al., 2005).

\section{Sample collection}

Snakes were collected in the urban area of the 
municipality of Rio Tinto through active searches and occasional encounters with the human population. Active searches were conducted four times a month, two hours each, by two or three researchers who searched for snakes on roads, rivers, vacant lots, and forest areas along the Rio Tinto urban from August 2009 to September 2012. These were previously known sites to find snakes. Local collectors provided additional records of snakes during this period. We informed the general populace about our research through community radio (once a week). We did not encourage people to search for, catch, or kill snakes, but usually when local residents find these animals in the urban area, they do kill them (França et al., 2012). We simply reported our phone numbers to local residents and asked them to contact one of our researchers to collect the animal. In addition, we also visited local community leaders and presented our research, requesting them also to call if there were any snakes in the area.

\section{GIS Analyses}

Each individual found was identified to the species level, and its geographic location recorded with a GPS unit. The perimeter of the study area was delimited using the SUDENE SB 25-Y-A-V4 NE (1974) map and a map of the Rio Tinto municipality (2005). The area was georeferenced and divided into $100 \times 100 \mathrm{~m}$ regular grids using ArcGIS 10.1 software developed by ESRI (2004), and all individuals present in each grid were counted.

\section{Ordinary kriging}

We used the spatial interpolation method called ordinary kriging, which uses mathematical functions to add more weight to the closest sample points and less weight to more distant sample points. From these data, new points are created based on these linear combinations. This procedure allows the generation of continuous surfaces from punctual sampling units. This analysis included all snake individuals and was not separated by species, as the purpose was to determine the points in the urban area where we could find more snakes. The data were run in the Geostatistical Analyst extension of ArcGIS 10.1 software (ESRI, 2004).

Before executing the kriging, we analysed the spatial variability of the data. This was achieved by examining the semivariogram, which is a graphical representation of the semivariances and the distances between sampled points. ArcGIS 10.1 uses a least squares method to fit the models, and as a criterion for model selection it uses the coefficient of determination and the sum of squares of residuals. From this procedure, the exponential model was adjusted to the interpolation of variables and acquisition of their parameters (nugget effect, partial sill, and major range). These parameters were used to create a map of snake density through ordinary kriging. The major range was also used to determine the appropriate distance between sampling points, as it represents the influence of the point on its neighbours. Thus, variables located at distances greater than the range have random spatial distribution and are considered independent between locations (Ge et al., 2005). As the maximum range found was $220.23 \mathrm{~m}$, the dimensions of the sampling grid (100 x 100 m cells) yielded an appropriate and qualified accurate detection of the snake distributions.

\section{Average Nearest Neighbour Distance}

We conducted the average nearest neighbour distance test using the Spatial Statistical Tools extension of ArcGIS 10.1 to detect the distribution patterns of 20 snake species within the study area. This tool is expressed as the ratio between the observed distance among individuals and the expected distance. The expected distance is the mean distance between neighbours in a hypothetical random distribution. This analysis provides three values: the index of the nearest neighbour (R-value), the value of $z$, and the $p$-value. A clustered distribution has an $\mathrm{R}$-value $<1$, while a dispersed distribution has an R-value $>1$. If the $R$-value $=1$, the default is considered random distribution. A z-value is calculated, which is compared to a critical $\mathrm{z}$ for the appropriate $\mathrm{N}$ and determines whether or not to reject the null hypothesis that says that distribution among individuals of each species within the area is random. If the $p$-value is too small $(p<0.01)$, it is very unlikely that the observed spatial pattern is the result of random processes, and thus the null hypothesis is rejected.

The minimum number required for analysis is three individuals; thus, the species Apostolepis cearensis Gomes, 1915, Boa constrictor, Drymoluber dichrous, Erythrolamprus almadensis, Sibon nebulatus, Spilotes pullatus, Spilotes sulphureus, Taeniophallus occipitalis, which were also found in urban areas but had fewer than three individuals and were excluded from the analysis.

\section{RESULTS}

We recorded 291 specimens distributed among 28 species, 22 genera, and 4 families (Boidae, Colubridae, Elapidae, and Viperidae) from the urban area of Rio Tinto. The most abundant species were Micrurus aff. ibiboboca $(\mathrm{N}=43)$, Helicops angulatus $(\mathrm{N}=41)$, and Bothrops leucurus $(\mathrm{N}=36)$. Snakes in this area were found in streets, houses, churches, at a university campus, streams, and even within local supermarkets. The venomous species that can cause lethal snakebites are from the families Elapidae and Viperidae. The points of occurrence of the snakes are shown in the map (Fig. 2). The significant results of the average nearest neighbour distance analysis indicated that $B$. leucurus and Philodryas olfersii had clustered distribution patterns, while Epicrates assisi, H. angulatus, Erythrolamprus poecilogyrus, Oxyrhopus trigeminus, Philodryas patagoniensis, P. nattereri, Xenodon merremii, and $M$. aff. ibiboboca presented dispersed distributions. Index values of the nearest neighbour (R), z-values, and corresponding $p$-values for each species are shown in Table 1.

The population map was prepared using the density of snakes, which ranged from 0-14 per grid (Fig. 3), and it demonstrated that the individuals' distribution area focused on three distinct points (in circles on the map). They are located in the centre of the urban area. 


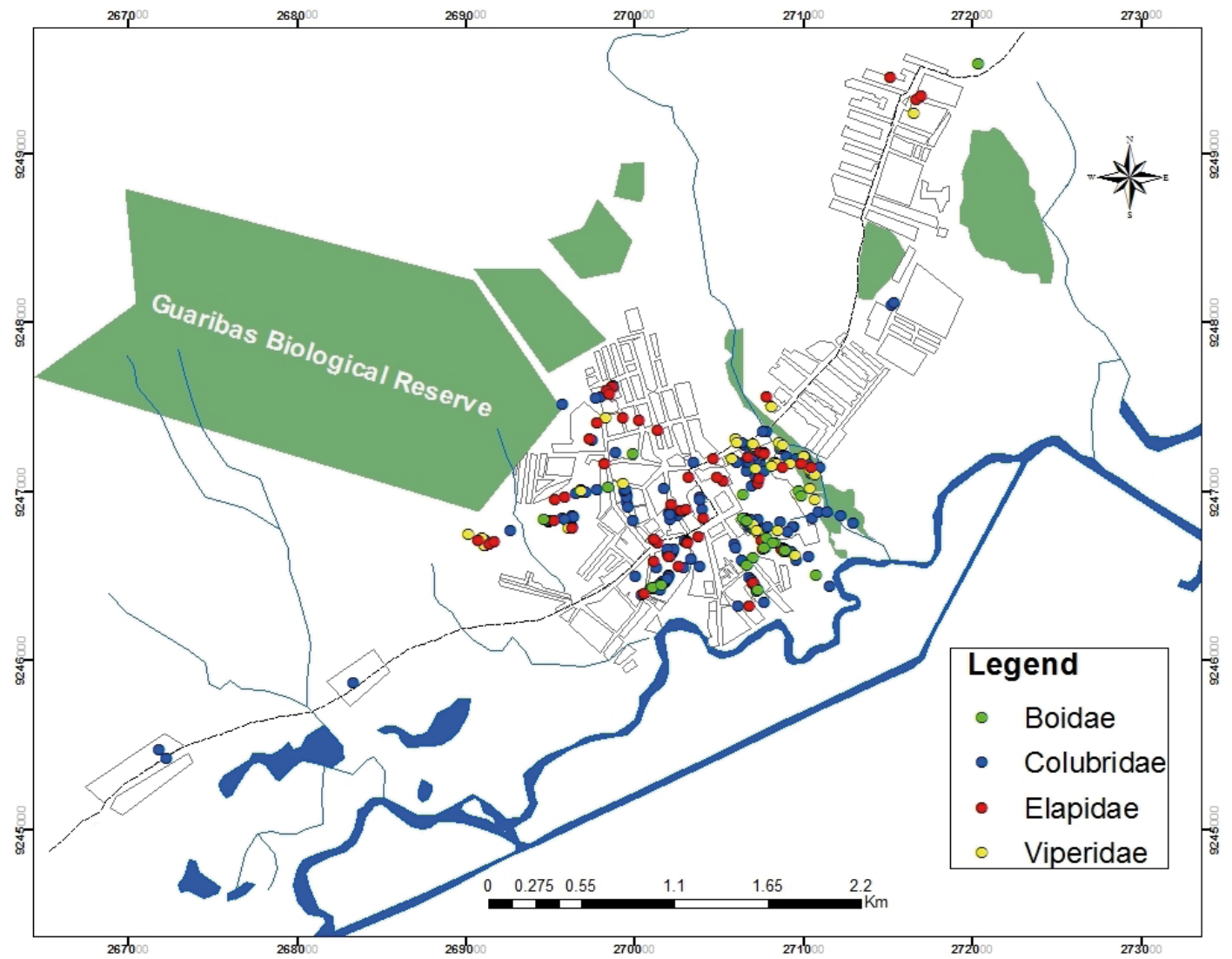

Figure 2. Distribution of snakes from the families Boidae, Colubridae, Elapidae, and Viperidae in the Rio Tinto urban area.

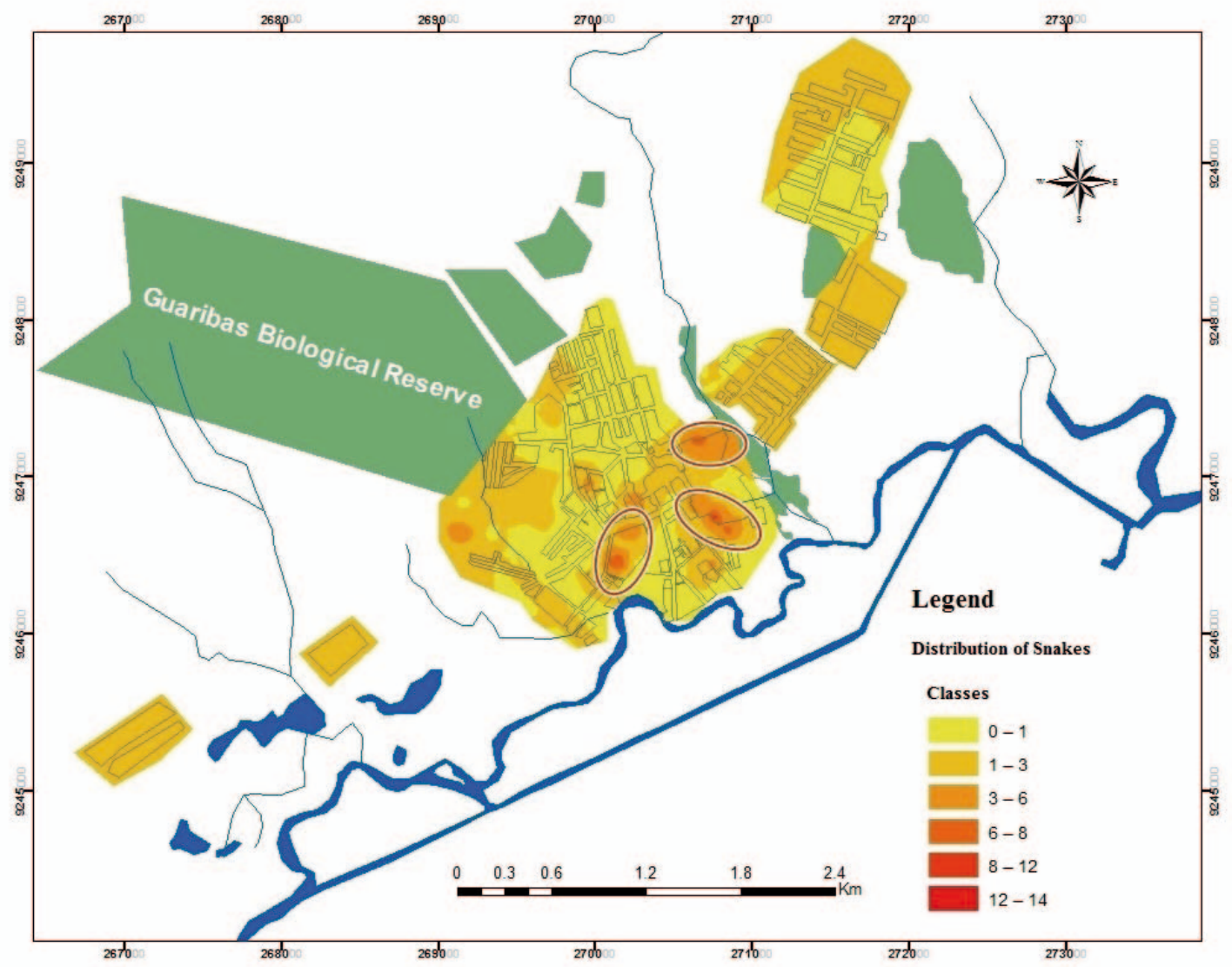

Figure 3. Spatial distribution of snakes in urban areas of the Rio Tinto municipality based on ordinary kriging. The darker colours represent points of higher probability of finding snakes, and the classes represent the number of individuals. 
Table 1. Results of the average nearest neighbour distance analysis, where $\mathrm{n}=$ number of individuals, $p=$ probability value, pattern = type of pattern shown by each species, $R=$ the index of the nearest neighbour, and $z=$ statistical significance

\begin{tabular}{|c|c|c|c|c|c|}
\hline Family/Species & $\mathbf{n}$ & $\mathbf{R}$ & $\mathbf{z}$ & $\mathbf{p}$ & Pattern \\
\hline \multicolumn{6}{|l|}{ Boidae } \\
\hline Epicrates assisi (Machado, 1946) & 22 & 29.37 & 254.57 & $<0.01$ & Dispersed \\
\hline \multicolumn{6}{|l|}{ Colubridae } \\
\hline Chironius flavolineatus (Jan, 1863) & 8 & 0.69 & 1.68 & $<0.1$ & Clustered \\
\hline Dipsas mikanii (Schlegel, 1837) & 10 & 0.79 & -1.27 & $<0.1$ & Clustered \\
\hline Erythrolamprus poecilogyrus (Wied, 1825) & 9 & 2.11 & 6.39 & $<0.01$ & Dispersed \\
\hline E. taeniogaster (Jan, 1863) & 6 & 0.46 & -2.57 & $<0.05$ & Clustered \\
\hline Helicops angulatus (Linnaeus, 1758) & 41 & 1.29 & 3.54 & $<0.01$ & Dispersed \\
\hline Leptophis ahaetulla (Linnaeus, 1758) & 10 & 1.16 & 1 & $<0.1$ & Random \\
\hline Lygophis dilepis (Cope, 1862) & 5 & 0.75 & -1.08 & $<0.1$ & Clustered \\
\hline Oxybelis aeneus (Wagler, 1824) & 4 & 0.69 & -1.2 & $<0.1$ & Clustered \\
\hline Oxyrhopus petolarius (Linnaeus, 1758) & 4 & 0.4 & -2.31 & $<0.05$ & Clustered \\
\hline O. trigeminus Duméril (Bibron \& Duméril, 1854) & 10 & 1.64 & 3.88 & $<0.01$ & Dispersed \\
\hline Philodryas patagoniensis (Girard, 1858) & 17 & 1.46 & 3.65 & $<0.01$ & Dispersed \\
\hline P. nattereri Steindachner, 1870 & 4 & 3.75 & 10.53 & $<0.01$ & Dispersed \\
\hline P. olfersii (Lichtenstein, 1823) & 17 & 0.59 & -3.21 & $<0.01$ & Clustered \\
\hline Psomophis joberti (Sauvage, 1884) & 3 & 1.57 & 1.9 & $<0.1$ & Dispersed \\
\hline Pseudoboa nigra (Duméril, Bibron \& Duméril, 1854) & 12 & 0.81 & -1.17 & $<0.1$ & Clustered \\
\hline Xenodon merremii (Wagler, 1824) & 6 & 2.09 & 5.12 & $<0.01$ & Dispersed \\
\hline \multicolumn{6}{|l|}{ Elapidae } \\
\hline Micrurus aff. ibiboboca & 43 & 1.85 & 10.65 & $<0.01$ & Dispersed \\
\hline M. potyguara Pires, Silva, Feitosa, Prudente, Pereira-Filho \& Zaher, 2014 & 11 & 1.15 & 0.97 & $<0.1$ & Random \\
\hline \multicolumn{6}{|l|}{ Viperidae } \\
\hline Bothrops leucurus (Wagler, 1824) & 36 & 0.65 & -4.01 & $<0.01$ & Clustered \\
\hline
\end{tabular}

\section{DISCUSSION}

In this study, we observed that the points of highest occurrence of snakes were near rivers. This fact might be linked to the abundance of food that these places offer. The rivers are surrounded by green areas, and these areas maintain other populations of animals, such as frogs and small mammals, which are potential prey for snakes. Conversely, forested areas concentrate a large number of species but decrease the rate of encounters with snakes by the human population, which is probably caused by the permanence of snakes in their microhabitats in the forests (Barbo, 2008).

Due to the constant loss of natural environments, squamate species have been forced to expand their home range into other areas, including urban areas (Mitchell \& Brown, 2008). Groves, vacant lots, back yards of houses, and rivers are some of the sites that act as refuges for these animals, providing shelter and food (Barbo, 2008; Brites \& Bauab, 1988; Puorto et al., 1991). Thus, encounters between people and snakes are more likely near these places. Most snake species found in the urban area of Rio Tinto are not venomous (França et al., 2012) and therefore do not present a risk to humans. However, there are dangerous species from the families Elapidae and Viperidae that can cause lethal snakebites (Cardoso et al., 2003). This scenario is aggravated because some of these species have high abundance in the urban areas (França et al., 2012).
The presence of snakes of genus Bothrops in urban areas of Brazilian municipalities has often been documented (Barbo et al., 2011; Brites \& Bauab, 1988; Puorto et al., 1991; Carvalho \& Nogueira, 1998; Costa et al., 2010; Marques et al., 2009; Sao Pedro \& Pires, 2009). This can be due to their feeding habits, as most Bothrops species feed mainly on small rodents, which are abundant in urban areas. Individuals of this species were captured near residences but were generally more restricted to sites within the urban area near fragments of natural habitats. Bothrops individuals recorded by Puorto et al. (1991) and Barbo (2008) in urban areas of the municipality of São Paulo and by Brites \& Bauab (1988) in urban areas of the municipality of Uberlândia were also associated with forest fragment. This indicates that although Bothrops species are often recorded in urban areas, these snakes are not as tolerant to anthropogenic environments, given that they appear in urban areas associated to patches of natural habitats. Thus, the distribution pattern found may be related to environmental conditions such as temperature, humidity, and vegetation cover, rather than solely because of prey availability.

The genus Micrurus, which is ecologically different from Bothrops, showed a wide distribution in the urban area of Rio Tinto, and some individuals were even collected within homes, churches, and local markets. This was also recorded by Brites \& Bauab (1988), who found specimens deeper into the urban matrix. These snakes seem to have a high degree of environmental 
plasticity, living well both in natural areas and in anthropogenic environments. The abundance of coral snakes in the wild is still poorly understood; however, it is certain that associative aspects of soil, vegetation, temperature, precipitation, and humidity influence their abundance, as well as the availability of food (Marques et al., 2006; Almeida et al., 2016). One reason that may favour the wide distribution of elapids in urban areas is their ophiophagous habit. Lema et al. (1983) noted that Micrurus are usually collected in places where an abundance of other snakes is found.

Despite the fact that it was more widely distributed in the urban area of Rio Tinto, the genus Micrurus did not exhibit aggressive behaviour, and this may explain the absence of accidents involving these snakes in the region. Still, their abundance and proximity to human population needs further attention, as it is a highly venomous species. Bothrops are more aggressive than Micrurus, which increases the occurrence of accidents (Strauch et al., 2018). In a study by Albuquerque et al. (2005), where records of 1098 patients bitten by Bothrops in the state of Paraíba was investigated, the municipality of Rio Tinto ranked second in number of notifications, with $1.5 \%$ of snakebites in the state.

Although traditionally only species from the families Elapidae and Viperidae are called venomous, some cases of human envenomation by dipsadids, which have opisthoglyphous dentition, have been recorded in Brazil (Araújo \& Santos, 1997; Bernarde, 2011). Some cases have involved species of the genus Philodryas, and a case of envenomation by Philodryas olfersii was even recorded in the urban area of Rio Tinto in 2015. Locals should take some care in dealing with these snakes, as that family is the most diverse in the area, and thus a better knowledge of snake species the region is warranted to avoid accidents with potentially dangerous snakes otherwise believed to be inoffensive.

Species of Philodryas (usually found in open areas) are the most frequently recorded snakes in the literature on urban areas in Brazil (e.g. Carvalho \& Nogueira, 1998; Bernarde \& Machado, 2002; Costa et al., 2010; Sousa et al., 2010; França et al., 2012). Intuitively, their adaptation to open areas may facilitate the use of urban and anthropic matrices. However, Hartmann \& Marques (2005) compared the habitats of $P$. olfersii and $P$. patagoniensis and found the first species near forest fragments and the second mainly in open areas. Herein, both $P$. patagoniensis and $P$. nattereri present dispersed distribution patterns which contrasted with the clustered pattern observed for $P$. olfersii. While former two species have generalist diets, feeding on mammals, birds, lizards, and amphibians (Vitt \& Vangilder, 1983; Hartmann \& Marques, 2005), P. olfersii seems to prey exclusively on frogs (Hartmann \& Marques, 2005), and hence is most commonly found near rivers and fragments of natural habitats. Also, due to the green colour pattern of $P$. olfersii, it is likely less perceptible to predators and humans in vegetation-covered environments.

Other common snakes found in Rio Tinto are grass snakes of genus Erythrolamprus and the water snake Helicops angulatus. According to Dixon (1981), snakes of the genus Liophis (currently Erythrolamprus - see Grazziotin et al., 2012) have generalist diets. However, some species seem to be frog specialists (Strussmann \& Sazima, 1993). Erythrolamprus poecilogyrus showed higher abundances in areas near water bodies, where there should be higher densities of frogs. Also showing a dispersed distribution pattern, the water snake $H$. angulatus, an aquatic species that feeds on fish and frogs (Ford \& Ford, 2002), was also found along rivers within in the urban area, especially during rainy months.

In general, we recognised three areas with riparian environments, including streams, rivers, and mangroves, which are the main places where snakes are found in Rio Tinto. One is a mangrove area used by local people for fishing and recreation, and thus the rate of casual encounters with a snake is higher, many of which are commonly harmful (Greene, 2000). Therefore, information on the sites where snakes are more likely to be found in and near urban areas is important not only for conservation (Brites \& Bauab, 1988), but for society in general. Understanding where dangerous species are more likely to be found helps to reduce the likelihood of accidents, possibly contributing to a more harmonic interaction between people and snakes, also warning locals to avoid these areas.

\section{ACKNOWLEDGEMENTS}

We thank Davi L. Pantoja and Fagner D. Ribeiro for their comments and suggestions on the manuscript, and to Isabella M. M. C. Pedrosa for your help with the English. We also thank the Núcleo de Ecologia de Serpentes NESUFPB for their help in fieldwork. RCF thanks FAPESB for a PhD scholarship (BOL0353/2016) and CNPq for Doutorado Sanduíche no Exterior (SWE) scholarship (208442/2017-0). FGRF thank CNPq (Universal grant $404671 / 2016-0)$ for their financial support.

\section{REFERENCES}

Albuquerque, H.N., Guedes, T.B. \& Cavalcanti, M.L. (2005). Estudo dos acidentes ofídicos provocados por serpentes do gênero Bothrops notificados no estado da Paraíba. Revista de Biologia e Ciências da Terra 5, 1-8.

Almeida, P.C.R., Prudente, A.D.C., Curcio, F.F. \& Rodrigues, M.T.U. (2016). Biologia e História Natural das Cobras-Corais. In As Cobras Corais do Brasil: Biologia, Taxonomia, Venenos e Envenenamentos, 168-215. Silva Jr, N.J. (ed). PUC, Goiás.

Araújo, M.E. \& Santos, A.C. (1997). Cases of human envenoming caused by Philodryas olfersii and Philodryas patagoniensis (Serpentes: Colubridae). Revista da Sociedade Brasileira de Medicina Tropical 30, 517-519.

Barbo, F.E. (2008). Os Répteis no Município de São Paulo: Aspectos Históricos, Diversidade e Conservação. In Além do Concreto: Contribuições Para a Proteção da Biodiversidade Paulistana, 234-267. Malagoli, L.R., Bajestero,F.B. \& Whately, M. (eds). Editora Instituto Socioambiental, São Paulo.

Barbo, F.E., Marques, O.A.V. \& Sawaya, R.J. (2011). Diversity, natural history, and distribution of snakes in the municipality of São Paulo. South American Journal of Herpetology 6, 135-160. 
Beltrão, B.A., Morais, F., Mascarenhas, J.C., Miranda, J.L.F., Souza Junior, L.C. \& Mendes, V.A. (2005). Projeto cadastro de fontes de abastecimento por água subterrânea estado de Paraíba: Diagnóstico do município de Rio Tinto. CPRM, Recife.

Bernarde, P.S. (2011). Mudanças na classificação de serpentes peçonhentas brasileiras e suas implicações na literatura médica. Gazeta Médica da Bahia 85, 55-63.

Bernarde, P.S. \& Machado, R.A. (2002). Fauna Reptiliana da Bacia do Rio Tibagi. In A Bacia do Rio Tibagi, 291-296. Londrina: MC-Gráfica.

Bieser, N.D. (2008). Spatial ecology and survival of resident juvenile and headstarted Eastern Massasauga (Sistrurus catenatus catenatus) in Northern Michigan, MS thesis, Purdue University.

Brites, V.L.C. \& Bauab, F.A. (1988). Fauna ofidiana do municipio de Uberlândia, Minas Gerais - Brasil - I. Ocorrência na área urbana. Revista do Centro de Ciências Biomédicas da Universidade Federal de Urberlândia 4, 3-8.

Brito, J.C., Santos, X., Pleguezuelos, J.M. \& Sillero, N. (2008). Inferring evolutionary scenarios with Geostatiscs and geographical information systems (GIS) for the viperid snakes Vipera lasatei and V. monticola. Biological Journal of the Linnean Society 95, 790-806.

Browning, D.M., Beaupre, S.J. \& Duncan, L. (2005). Using partitioned Mahalanobis D2(K) to formulate a GIS-based model of timber rattlesnake hibernacula. Journal of Wildlife Management 69, 33-44.

Cardoso, J.L.C., França, F.O.S., Wen, F.H., Málaque, C.M.S. \& Haddad Jr., V. (2003). Animais Peçonhentos no Brasil: Biologia, Clínica e Terapêutica dos acidentes. Sarvier: São Paulo.

Carvalho, M.A. \& Nogueira, F.N. (1998). Serpentes da área urbana de Cuiabá, Mato Grosso: aspectos ecológicos e acidentes ofídicos associados. Cadernos de Saúde Pública $14,753-763$

Clark, P.J. \& Evans, F.C. (1954). Distance to nearest neighbor as a measure of spatial relationships in populations. Ecological Society of America 35, 445-453.

Cooper-Doering, S. (2005). Modeling rattlesnake hibernacula on the Idaho National Laboratory, Idaho. MS Thesis, Idaho State University, Pocatello.

Costa, H.C., Pantoja, D.L., Pontes, J.L. \& Feio, R.N. (2010). Snakes of the municipality of Viçosa, Atlantic Forest of southeastern Brazil . Biota Neotropica 10, 354-377.

Dal Prá, E., Guedes, J.V.C., Cherman, M.A., Jung, A.H., Silva, S.J.P. \& Ribas, G.G. (2011). Uso da geoestatística para caracterização da distribuição espacial de larvas de Diloboderus abderus. Ciência Rural 41, 1689-1694.

Degregorio, B.A. (2008). Response of the Eastern Massasauga (Sistrurus catenatus catenatus) to Clear-Cutting. MS thesis, Purdue University, Fort Wayne, Indiana.

Dixon, J.R. (1981). The Neotropical colubrid snake genus Liophis: The Eastern Caribbean Complex. Copeia, 296-304.

Ford, N.B. \& Ford, D.F. (2002). Notes on the ecology of the South American water snake Helicops angulatus (Squamata: Colubridae) in Nariva Swamp, Trinidad. Caribbean Journa of Science 38, 129-132.

França, R.C., Germano, C.E.S. \& França, F.G.R. (2012). Composition of a snake assemblage inhabiting an urbanized area in the Atlantic Forest of Paraíba State, Northeast Brazil.
Biota Neotropica 12, 183-195.

Ge, S.K., Carruthers, R.I., Ma, Z.F., Zhang, G.X. \& Li, D.M. (2005). Spatial heterogeneity and population risk analysis of cotton bollworm, Helicoverpa armigera, in China. Insect Science 12, 255-262.

Grazziotin, F.G., Zaher, H., Murphy, R.W., Scrocchi, G., Benavides, M.A., Zhang, Y.P. \& Bonatto, S.L. (2012). Molecular phylogeny of the new world dipsadidae (serpentes: Colubroidea): A reappraisal. Cladistics 28, 437-459.

Greene, H.W., Fogden, M. \& Fogden, P. (2000). Snakes. The Evolution of Mystery in Nature. Univ of California Press.

Hamer, A.J. \& Mcdonnell, M.J. (2010). The response of herpetofauna to urbanization: Inferring patterns of persistence from wildlife databases. Austral Ecology 35, 568-580.

Hartmann, P.A. \& Marques, O.A.V. (2005). Diet and habitat use of two sympatric species of Philodryas (Colubridae), in south Brazil. Amphibia-Reptilia 26, 25-31.

Jenkins, C.L., Peterson, C.R. \& Kingsbury, B.A. (2009). Modeling Snake Distribution and Habitat. In Snakes: Ecology and Conservation, 123-148. MULLIN, S.J. \& SEIGEL, R.A. (eds.). Ithaca, New York, USA: Comstock Publishing Associates.

Lee, J.R. \& Peterson, C.R. (2003). Herpetological Inventory of Craters of the Moon National Monument 1999-2001. Final Report to Craters of the Moon National Monument and Preserve, National Park Service, Pocatello, Idaho.

Lema, T.D, Araujo, M.L.D. \& Azevedo, A.C.P. (1983). Contribuição ao conhecimento da alimentação e do modo alimentar de serpentes do Brasil. Comunicações do Museu de Ciências da PUCRS 26, 41-121.

Levin, S.A. (1992). The problem of pattern and scale in ecology: The Robert H. MacArthur award lecture. Ecology 73, 1943.

Marques, O.A., Almeida-Santos, S.M. \& Rodrigues, M.G. (2006). Activity patterns in coral snakes, genus Micrurus (Elapidae), in South and Southeastern Brazil. South American Journal of Herpetology 1, 114-121.

Marques, O.A.V, Pereira, D.N., Barbo, F.E., Germano, V.J. \& Sawaya, R.J. (2009). Reptiles in São Paulo municipality: Diversity and ecology of the past and present fauna. Biota Neotropica 9, 139-150.

Martínez-Freiría, F., Santos, X., Pleguezuelos, J.M., Lizana, M. \& Brito, J.C. (2009). Geographical patterns of morphological variation and environmental correlates in contact zones: A multi-scale approach using two Mediterranean vipers (Serpentes). Journal of Zoological Systematics and Evolutionary Research 47, 357-367.

McKinney, M.L. (2006). Urbanization as a major cause of biotic homogenization. Biological Conservation 127, 247-260.

Mesquita DO, Alves BCF, Pedro CKB, et al (2018) Herpetofauna in two habitat types (tabuleiros and Stational Semidecidual Forest) in the Reserva Biológica Guaribas, northeastern Brazil. Herpetology Notes 11,455-474

Mitchell, J.C., Brown, R.E.J. \& Bartholomew, B. (2008). Urban Herpetology. Herpetological Conservation, 3, 130, Naiman.

Mitchell, J.C. \& Jung Brown, R.E. (2008). Urban herpetology: global overview, synthesis, and future directions. Herpetological Conservation 3, 1-30.

Oliveira-Filho, A.T. \& Carvalho, D.A. (1993). Florística e fisionomia da vegetação no extremo norte do litoral da Paraíba. Revista Brasileira de Botânica 16, 115-130.

Peterson, C. R., Cossel jr, J. O., Pilliod, D. \& Bean, B. M. (2002). 
The occurrence, distribution, relative abundance, and habitat relationships of amphibians and reptiles on the Idaho Army National Guard Orchard Training Area, Ada County, Idaho. Final Report to the Idaho Army National Guard.

Puorto, G., Laporta-Ferreira, I.L. \& Sazima, I. (1991). Serpentes na selva de pedra. Ciência Hoje 13, 66-67.

Rojas-Morales, J.A. (2012). Snakes of an urban-rural landscape in the central Andes of Colombia: Species composition, distribution, and natural history. Phyllomedusa 11, 135154.

Rosa, C.L. (2010). Educação e Salvaguarda do Patrimônio Industrial: A Cidade Operária de Rio Tinto, Brasil. Dissertação de Mestrado, Université Paris, Paris.

Sales, R.F.D., Lisboa, C.M.C.A. \& Freire, E.M.X. (2009). Répteis Squamata de remanescentes florestais do Campus da Universidade Federal do Rio Grande do Norte, Natal-RN, Brasil. Cuadernos de Herpetología 23, 77-88.

Santos, T.G., Koop, K.A., Spies, M.R., Trevisan, R. \& Cechin, S.Z. (2005). Répteis do campus da Universidade Federal de Santa Maria, RS, Brasil. Biota Neotropica 5, 171-178.

São Pedro, V.A. \& Pires, M.R.S. (2009). Snakes of Ouro Branco region, south of Espinhaço range, Minas Gerais. As serpentes da região de Ouro Branco, extremo sul da Cadeia do Espinhaco, Minas Gerais. Revista Ceres 56, 166-171.
Scott, J.M., Peterson, C.R., Karl, J. W., Strand, E., Svancara, L. K. \& Wright, N. M. (2002). A Gap analysis of Idaho: final report. Idaho Cooperative Fish and Wildlife Research Unit, Moscow, ID.

Silva, R.C.A. \& Ferreira, I.L.L. (1988). A ofíofauna da região urbana de Guarulhos (Grande São Paulo). Alterações ocorridas no período de 1930 a 1990. Revista Universidade Guarulhos 3, 77-81.

Sousa, B.M.D., Nascimento, A.E.R.D, Gomides, S.C., Rios, C.H.V., Hudson, A.D.A. \& Novelli, I.A. (2010). Répteis em fragmentos de Cerrado e Mata Atlântica no Campo das Vertentes, Estado de Minas Gerais, Sudeste do Brasil. Biota Neotropica 10, 129-138.

Strauch, M.A., Souza, G.J., Pereira, J.N., Ramos, T. S., Cesar, M.O., Tomaz, M.A., Monteiro-Machado, M., Patrão-Neto, F.C. \& Melo, P.A. (2018). True or false coral snake: is it worth the risk? A Micrurus corallinus case report. Journal of venomous animals and toxins including tropical diseases 24, 1-5.

Strussmann, C. \& Sazima, I. (1993). The snake assemblage of the Pantanal at Poconé, Western Brazil: Faunal composition and ecological summary. Studies on Neotropical Fauna and Environment 28, 157-168.

Vitt, L. J., \& Vangilder, L. D. (1983). Ecology of a snake community in Northeastern Brazil. Amphibia-Reptilia 4, 273-296.

Accepted: 10 July 2019 